\title{
Editorial v. 31, n. 1 (2019)
}

Iniciamos este ano de 2019 com muitos desafios, assim como celebramos mais uma edição de nossa Revista. Mantemos o compromisso ético de publicar artigos científicos relevantes para o nosso campo de conhecimento, que se caracteriza pelos estudos da subjetividade. Podemos perceber o fortalecimento do campo e da importância da Fractal pelo número de artigos que recebemos anualmente e, também, pela qualidade daqueles que chegam ao processo final de avaliação. Reafirmo, como já disse em outro editorial, a importância dos pareceristas ad hoc, que dedicam um pouco de seu tempo, em meio às inúmeras exigências, para emitir pareceres que norteiam nossas publicações. Friso, ainda, a importância da qualidade desses pareceres para que a nossa Revista se mantenha no patamar de credibilidade que alcançamos. São 30 anos de muitos investimentos - financeiros, científicos, subjetivos, afetivos. Muitos avanços foram feitos para agilizar nossa plataforma, a despeito das dificuldades. Hoje temos uma funcionária dedicada e competente que nos ajuda nos trâmites, sempre difíceis e demorados, de nossos artigos. Agradeço, portanto, neste editorial, à chegada de Cláudia Castanheira à nossa equipe. Além disso, hoje contamos com alunos voluntários, que estão nos ajudando na melhoria da qualidade dos artigos postos na plataforma - aproveito para pedir aos autores que estejam atentos às normas da Revista, uma vez que não serão mais aceitos artigos que não observarem as normas de publicação.

Em relação a este número que agora publicamos, gostaria de destacar o fato de que três artigos, dentre os oito aqui apresentados, são da região Nordeste, sendo que um deles, intitulado "Por trás da máscara da loucura: cenários e desafios da assistência à pessoa com esquizofrenia no âmbito da Atenção Básica" - voltado para os desafios da saúde mental neste momento tão crucial de nosso país -, foi produzido fora de uma capital. Destaco, ainda, a diversidade dos temas trazidos, ligados à influência de autores como Foucault, Vigotski, Jung e Freud na produção de conhecimento no Brasil - mostrando como temos articulado este conhecimento e feito nossos escritos acadêmicos em nosso próprio território. Estes artigos são: A recepção das premissas de Haeckel na obra de Jung; Um olhar sobre a "vivência" através do seu autor: conceitos e traduções na obra de Vigotski e Diálogos da Psicologia com Michel Foucault. Sabemos da importância desta proposta, uma vez que afirmamos a diversidade nos estudos da subjetividade pautada, dentre outros critérios, pela variedade de autores citados e de propostas metodológicas. A diversidade também está presente na proposta de articular o pensamento ocidental com os sonhos (A tecnologia de gestão coletiva dos sonhos), com a subjetividade sindical (A trama de vínculos na história de um representante sindical) ou com as mulheres beneficiárias do Programa Bolsa Família (Subjetividades de beneficiárias do Programa Bolsa Família em contexto rural).

Desta forma, podemos apresentar este primeiro volume da Fractal como uma afirmação do conhecimento científico pautado no respeito e na abertura de espaço para a proliferação de artigos científicos que façam com que diversas vozes sejam ouvidas. Como nos mostra o artigo A movimentação das palavras: devir-construção no feminino da escrita, precisamos estar aliados àqueles que, em muitos momentos, são negligenciados, para construir um conhecimento que faça sentido para muitos e não apenas para um número reduzido de pessoas. Sigamos em nossa proposta de divulgação da produção científica brasileira, feita por brasileiros e para brasileiros. Que a internacionalização aconteça, valorizando também o conhecimento produzido no hemisfério Sul de nosso planeta.

Ana Claudia Lima Monteiro

Editora de Fractal: Revista de Psicologia 